Научная статья

УДК 615.322

DOI: $10.18101 / 2306-1995-2021-1-52-57$

\title{
РАЗРАБОТКА МЕТОДИКИ КОЛИЧЕСТВЕННОГО ОПРЕДЕЛЕНИЯ СУММЫ ФЛАВОНОИДОВ В ARTEMISIA SUBVISCOSAE HERBA
}

\author{
(C) Преловская Саяна Зориктоевна \\ старший преподаватель, \\ Бурятский государственный университет имени Доржи Банзарова \\ Россия, 670002, г. Улан-Удэ, ул. Октябрьская 36а \\ sayana.tsybicova@gmail.com
}

\section{(с) Рандалова Туяна Эрдэмовна}

кандидат фармацевтических наук, доцент,

Бурятский государственный университет имени Доржи Банзарова

Россия 670002, г. Улан-Удэ, ул. Октябрьская 36а

soktoevate@gmail.com

\author{
(C) Раднаева Лариса Доржиевна \\ доктор химических наук, профессор, \\ заведующая лабораторией химии природных систем, \\ Байкальский институт природопользования \\ Россия, 670047, г. Улан-Удэ, ул. Сахьяновой, 6 \\ заведующая кафедрой фармации, \\ Бурятский государственный университет имени Доржи Банзарова \\ Россия 670002, г. Улан-Удэ, ул. Октябрьская 36а \\ radld@mail.ru
}

Аннотация. В статье представлены результаты исследования по разработке методики количественного определения суммы флавоноидов в надземной части полыни клейковатой методом УФ-спектрофотометрии. Снят полный спектр спиртового извлечения в комплексе с хлоридом алюминия, максимум поглощения при длине волны 400 нм испытуемого раствора соответствует максимуму поглощения спектра лютеолин-7-гликозида с хлоридом алюминия. Подобраны оптимальные условия экстракции: тип экстрагента - спирт этиловый 40\%-ный, степень измельченности сырья - 1 мм, соотношение сырье - экстрагент - 1:50, температура - кипящая водяная баня, время экстракции 30 мин, двукратно. В качестве комплексообразователя использовали 2 мл 2\%-ного раствора хлорида алюминия, комплекс образуется в течение 45 мин. Содержание суммы флавоноидов в пересчете на лютеолин-7-гликозид в A. subviscosa herba составляет $2,03 \pm 0,04 \%$. Относительная ошибка предложенной методики не превышает 5\%.

Ключевые слова: Asteraceae, Artemisia L., Artemisia subviscosa, фенольные соединения, флавоноиды

\section{Для цитирования}

Преловская С. З., Рандалова Т. Э., Раднаева Л. Д. Разработка методики количественного определения суммы флавоноидов в Artemisia Subviscosae Herba // Вестник Бурятского государственного университета. Медицина и фармация. 2021. № 1. С. 52-57. 
С. З. Преловская, Т. Э. Рандалова, Л. Д. Раднаева. Разработка методики количественного определения суммы флавоноидов в Artemisia Subviscosae Herba

Введение. Природные соединения, содержащиеся в растениях, обладают широким спектром фармакологической активности, малой токсичностью или отсутствием таковой, а мягкость воздействия определяет возможность их длительного применения. Богатым источником фенольных и терпеновых соединений являются растения рода Artemisia L., широко применяемые в народной и традиционной медицине разных стран в качестве противовоспалительных, капилляроукрепляющих, желчегонных, противоопухолевых, и антиоксидантных средств [1]. Artemisia subviscosa Turcz. ex Bess. - ксерофитный полукустарничек, эндемик, произрастает в степях Баргузинской долины и на северо-западном побережье Байкала. Сложная орография местности, сочетание широтной и высотной поясности, влияние озера Байкал, низкая сельскохозяйственная освоенность горных и предгорных территорий позволяют предположить, что в эндемичных видах растений данного региона можно обнаружить уникальные биологически активные вещества [2]. Известны только данные химического состава эфирных масел этого вида [3-5].

Материалы и методы. Материалом для исследования служили образцы надземной части полыни клейковатой, собранные в 2018 г. в Баргузинском районе Республики Бурятия (окрестности с. Улюн и Ярикта) в фазе цветения. Количественное определение флавоноидов проводили методом УФспектрофотометрии на спектрофотометре ПЭ-5400 УФ (Экохим) в кварцевых кюветах с толщиной поглощающего слоя 10 мм в пяти повторностях. Снят полный спектр водно-спиртового извлечения A. subviscosae herba в комплексе с $2 \%$-ным раствором хлорида алюминия, максимум поглощения отмечен при 400 нм, что соответствует максимуму поглощения ГСО лютеолин-7-гликозида с хлоридом алюминия (рис. 1).

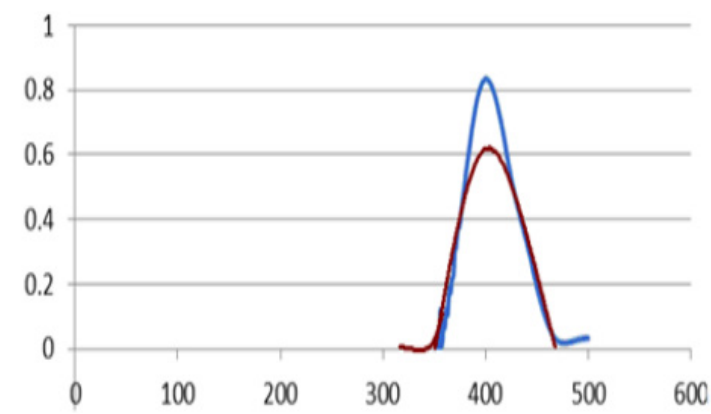

Рисунок 1. Спектр поглощения водно-спиртового извлечения A. subviscosae herba и СО лютеолин-7-гликозида

Таким образом, для разработки методики количественного определения суммы флавоноидов в A. subviscosae herba в качестве стандартного образца выбран лютеолин-7-гликозид, также необходимо определить условия выделения: тип экстрагента, размер частиц сырья, температуру нагревания, соотношение сырье - экстрагент, длительность и количество экстракций, объем раствора хлорида алюминия, необходимого для комплексообразования, концентрация раствора хлорида алюминия, время, необходимое для образования комплекса. 
Результаты и обсуждение. В ходе разработки методики экспериментально определены условия, обеспечивающие наибольший выход суммы флавоноидов из надземной части полыни клейковатой: экстрагент - спирт этиловый 40\%-ный, степень измельчения сырья (1 мм), соотношение сырье - экстрагент (1:50), температура нагрева — кипящая водяная баня (табл. 1).

Таблица 1

Зависимость выхода суммы флавоноидов в пересчете на лютеолин-7-гликозид из A. subviscosae herba от условий экстракции

\begin{tabular}{|c|c|}
\hline Условия экстракции & $\begin{array}{l}\text { Сумма флавоноидов в пересчете на лютео- } \\
\text { лин-7-гликозид, } \%\end{array}$ \\
\hline \multicolumn{2}{|l|}{ Тип экстрагента } \\
\hline 10\%-ный этанол & 1,25 \\
\hline 20\%-ный этанол & 1,40 \\
\hline 30\%-ный этанол & 1,70 \\
\hline 40\%-ный этанол & 2,10 \\
\hline 50\%-ный этанол & 1,57 \\
\hline 60\%-ный этанол & 1,16 \\
\hline 70\%-ный этанол & 1,10 \\
\hline 80\%-ный этанол & 0,98 \\
\hline 90\%-ный этанол & 0,85 \\
\hline 95\%-ный этанол & 0,72 \\
\hline \multicolumn{2}{|c|}{ Степень измельчения сырья, мм } \\
\hline 0,5 & 1,96 \\
\hline 1 & 2,32 \\
\hline 2 & 2,10 \\
\hline 3 & 1,81 \\
\hline 4 & 1,50 \\
\hline \multicolumn{2}{|l|}{ Температура, ${ }^{\circ} \mathrm{C}$} \\
\hline 20 & 1,30 \\
\hline 40 & 1,43 \\
\hline 60 & 1,51 \\
\hline 80 & 1,93 \\
\hline 100 & 2,10 \\
\hline \multicolumn{2}{|c|}{ Соотношение сырье - экстрагент } \\
\hline $1: 25$ & 1,65 \\
\hline $1: 50$ & 2,03 \\
\hline $1: 75$ & 1,84 \\
\hline $1: 100$ & 1,50 \\
\hline $1: 150$ & 1,15 \\
\hline
\end{tabular}

При определении оптимального времени экстрагирования A. subviscosae herba трехкратно экстрагировали в течение 15-90 мин с шагом 15 мин. После каждой экстракции жидкость отфильтровывали, проводили количественное определение суммы флавоноидов, после чего дважды экстрагировали отжатое 
С. З. Преловская, Т. Э. Рандалова, Л. Д. Раднаева. Разработка методики количественного определения суммы флавоноидов в Artemisia Subviscosae Herba

сырье в тех же условиях. Двукратная экстракция в течение 30 мин способствует большему выходу суммы флавоноидов из полыни клейковатой травы (табл. 2).

\section{Таблица 2}

Зависимость содержания суммы флавоноидов в пересчете на лютеолин-7-гликозид из A. subviscosae herba от времени экстракции

\begin{tabular}{|c|c|c|c|}
\hline \multirow{2}{*}{ Время экстракции, мин } & \multicolumn{3}{|c|}{$\begin{array}{c}\text { Сумма флавоноидов в пересчете } \\
\text { на лютеолин-7-гликозид, \% }\end{array}$} \\
\cline { 2 - 4 } & \multicolumn{3}{|c|}{ Кратность экстракции } \\
\cline { 2 - 4 } & 1 & 2 & 3 \\
\hline 15 & 1,55 & 0,61 & 0,07 \\
\hline $\mathbf{3 0}$ & $\mathbf{2 , 0 0}$ & $\mathbf{0 , 9 7}$ & $\mathbf{0 , 1 2}$ \\
\hline 45 & 1,86 & 0,79 & 0,07 \\
\hline 60 & 1,80 & 0,64 & 0,07 \\
\hline 75 & 1,65 & 0,53 & 0,05 \\
\hline 90 & 1,57 & 0,50 & 04 \\
\hline
\end{tabular}

Для определения оптимальных параметров комплексообразования использовали раствор хлорида алюминия в различных концентрациях (1-5\%) и объемах (1-5 мл), исследовали время, за которое образуется комплекс (15-90 мин). Выявлено, что оптимальной концентрацией хлорида алюминия является $2 \%$-ный раствор объемом 2 мл, комплекс образуется в течение 45-60 мин (табл. 3).

Таблийа 3

Зависимость содержания суммы флавоноидов в пересчете на лютеолин-7-гликозид в A. subviscosae herba от концентрации и объема хлорида алюминия, времени комплексообразования

\begin{tabular}{|l|c|}
\hline Показатель & $\begin{array}{l}\text { Сумма флавоноидов в пересчете на лютео- } \\
\text { лин-7-гликозид, \% }\end{array}$ \\
\hline Концентрация раствора $\mathrm{AlCl}_{3}, \%$ & 1,89 \\
\hline 1 & $\mathbf{1 , 9 8}$ \\
\hline $\mathbf{2}$ & 1,85 \\
\hline 3 & 1,85 \\
\hline 4 & 1,84 \\
\hline 5 & 1,92 \\
\hline Объем раствора $\mathrm{AlCl}_{3}$, мл & $\mathbf{2 , 0 0}$ \\
\hline 1 & 1,84 \\
\hline $\mathbf{2}$ & 1,76 \\
\hline 3 & 1,70 \\
\hline 4 & 1,90 \\
\hline 5 & 1,92 \\
\hline Время комплексообразования, мин & $\mathbf{1 , 9 5}$ \\
\hline 15 &
\end{tabular}




\begin{tabular}{|l|l|}
\hline 60 & 1,93 \\
\hline 75 & 1,87 \\
\hline 90 & 1,83 \\
\hline
\end{tabular}

Полученные параметры легли в основу методики количественного определения суммы флавоноидов полыни клейковатой травы. Метрологические характеристики методики количественного определения представлены в таблице 4.

Таблицуа 4

Метрологические характеристики результатов количественного определения суммы флавоноидов в пересчете на лютеолин-7-гликозид

\begin{tabular}{|l|l|l|l|l|l|l|l|l|}
\hline $\mathrm{n}$ & $\mathrm{f}$ & $\overline{\mathrm{x}}, \%$ & $\mathrm{~S}^{2}$ & $\mathrm{~S}$ & $\mathrm{P}, \%$ & $\mathrm{t}(\mathrm{P}, \mathrm{f})$ & $\Delta \mathrm{x}$ & $\mathrm{E}, \%$ \\
\hline 5 & 4 & 2,03 & 0,001 & 0,04 & 95 & 2,77 & 0,04 & 2,18 \\
\hline
\end{tabular}

Установлено, что содержание суммы флавоноидов в пересчете на лютеолин7-гликозид в надземной части полыни клейковатой составляет $2,03 \pm 0,04 \%$. Относительная ошибка методики не превышает 5\%.

Выводы. Таким образом, в результате проведенных исследований нами разработана методика количественного определения суммы флавоноидов в пересчете на лютеолин-7-гликозид в полыни клейковатой траве.

\section{Лuтература}

1. Асеева Т. А., Блинова К. Ф., Яковлев Г. П. Лекарственные растения тибетской медицины. Новосибирск: Наука, 1985. 160 с. Текст: непосредственный.

2. Анатомо-диагностические признаки и числовые показатели полыни клейковатой травы / С. З. Цыбикова, С. В. Жигжитжапова, Л. Д. Раднаева, И. Р. Балданова // Здоровье и образование в XXI веке. 2018. № 2. С. 107-111. Текст: непосредственный.

3. Бодоев Н. В., Базарова С. В., Намзалов Б. Б. Химический состав эфирного масла полыни клейковатой Artemisia subviscosa Turcz // Химия растительного сырья. 2002. № 1. C. 81-84. Текст: непосредственный.

4. Жигжитжапова С. В., Рандалова Т. Э., Раднаева Л. Д. Эфирное масло полыни клейковатой Artemisia subviscosa (Turcz. ex Bess.) Krasnob // Бюллетень ВСНЦ СО РАН. 2015. № 2 (102). С. 133-135. Текст: непосредственный.

5. Компонентный состав эфирного масла Artemisia subviscosa Turcz. ex Bess. / С. 3. Цыбикова, С. В. Жигжитжапова, Т. Э. Рандалова, Л. Д. Раднаева // Химия растительного сырья. 2019. № 4. С. 263-268. Текст: непосредственный.

Статья поступила в редакиию 09.01.2021; одобрена после рецензирования 25.01.2021; принята к публикациии 09.04.2021. 
С. З. Преловская, Т. Э. Рандалова, Л. Д. Раднаева. Разработка методики количественного определения суммы флавоноидов в Artemisia Subviscosae Herba

\section{DEVELOPMENT OF A METHOD FOR QUANTITATION \\ OF THE TOTAL FLAVONOIDS CONTENT IN ARTEMISIA SUBVISCOSAE HERBA}

Sayana Z. Prelovskaya

Senior Lecturer,

Dorzhi Banzarov Buryat State University

36a Oktyabrskaya St., Ulan-Ude 670002, Russia

sayana.tsybicova@gmail.com

Tuyana E. Randalova

Cand. Sci. (Chemistry), A/Prof.,

Dorzhi Banzarov Buryat State University

36a Oktyabrskaya St., Ulan-Ude 670002, Russia

soktoevate@gmail.com

Larisa D. Radnaeva

Dr. Sci. (Chemistry), Prof.,

Head of Laboratory of Natural Systems Chemistry

Baikal Institute of Nature Management

6 Sakhyanovoy St., Ulan-Ude 670047, Russia

Head of Pharmacy Department,

Dorzhi Banzarov Buryat State University

36a Oktyabrskaya St., Ulan-Ude 670002, Russia

radld@mail.ru

Abstract. The article presents a method for quantitation of the total flavonoids content in the aerial part of Artemisia subviscosa by UV-spectrophotometry. We have collected full spectral data on alcoholic extraction in a complex with aluminum chloride; the absorption maximum at a wavelength of $400 \mathrm{~nm}$ of the test solution corresponds to the absorption maximum of the spectrum of luteolin-7-glycoside with aluminum chloride. We have determined the optimal extraction conditions: type of extractant $-40 \%$ ethyl alcohol, grinding degree of raw materials $-1 \mathrm{~mm}$, ratio of raw materials to extractant $-1: 50$, temperature - boiling water bath, extraction time - $30 \mathrm{~min}$, twice. Aluminum chloride was used as a complexing agent ( $2 \mathrm{ml}$ of a $2 \%$ solution); the complex was formed within 45 minutes. The total flavonoids content equivalent to luteolin-7-glycoside in A. subviscosa herba is $2.03 \pm 0.04 \%$. The relative error of the proposed method does not exceed $5 \%$.

Keywords: Asteraceae, Artemisia L., Artemisia subviscosa, phenolic compounds, flavonoids

\section{For citation}

Prelovskaya S. Z., Randalova T. E., Radnaeva L. D. Development of a Method for Quantitation of the Total Flavonoids Content in Artemisia Subviscosae Herba. Bulletin of Buryat State University. Medicine and Pharmacy. 2021; 1: 52-57 (In Russ.).

The article was submitted 09.01.2021; approved after reviewing 25.01.2021; accepted for publication 09.04.2021. 